\title{
Islamic Transcendental Wellbeing Model for Malaysian Muslim Women: Implication on Counseling
}

\author{
Siti Aishah Hassan ${ }^{1}$ \\ ${ }^{1}$ Department of Counsellor Education and Counselling Psychology, Faculty of Educational Studies, Universiti \\ Putra Malaysia, Malaysia \\ Correspondence: Siti Aishah Hassan. Department of Counsellor Education and Counselling Psychology, Faculty \\ of Educational Studies, Universiti Putra Malaysia, 43000 Serdang UPM, Malaysia. Tel: 60-38-94-6816. E-mail: \\ siti_aishahh@upm.edu.my; siti8_aishah@yahoo.com
}

Received: June 30, 2014 Accepted: March 3, 2015 Online Published: July 6, 2015

doi:10.5539/ass.v11n21p331

URL: http://dx.doi.org/10.5539/ass.v11n21p331

\begin{abstract}
A great majority of the middle-aged women experience some degenerative physical symptoms, specifically pelvic prolapse which affected their quality of life. Accordingly, they may experience marital distress, divorces and depression. For younger women, among college students, cybersex addiction may likely affect their academic performances. Female are double as compared to male in the sexual addiction. Recent findings indicate that, spiritual wellbeing is the most satisfied domain among women in Malaysia. Yet, it does not correlate well with other domains, especially in economic. For single mothers, socio-economic status is indeed in crisis. Hence, there is a need to capitalize women's spirituality as inner resources for Muslim women's wellbeing. Therefore, we conceptualize a holistic model for Muslim Malaysian women wellbeing that integrates physical-sexual, socio-economical, and psycho-spiritual domains. Theoretically, this model helps to delineate Islamic transcendental theory that explains spiritual wellbeing permeates overall wellbeing. Finally, implications on counseling process are suggested
\end{abstract}

Keywords: wellbeing, spirituality, Islamic transcendental, psycho-spiritual, cybersex

\section{Introduction}

Women not only are the nucleus of families, but also the pillars of nations. In Malaysia, the contributions of women in multiple roles may not be overemphasis. Hence, the overall wellbeing of women is considered as the golden asset of nation has been reflected in National Women Policy (Dasar Wanita Negara, 1986). Women's wellbeing has also received substantial scholarly attention (Momtaz, Hamid, Masud, Haron, \& Ibrahim, 2013; Wan-Ibrahim, Majid, \& Zainab, 2014; Noor, Gandhi, Ishak, \& Wok, 2014). Due to overload of multiple roles responsibilities, multi-tasking seems to be the strength and strategy utilized by many women. Generally, from dawn to dusk, endless duties and expectations need to be met. This phenomenon has been documented in numerous empirical studies on work-family conflict among women (Noor et al., 2014; Ahmad, Baba, \& Hassan, 2009). Work overload has given a toll to women wellbeing. When the stress level reaches the threshold, women may not function well anymore. They are double as compare to man in depression (Khoosboii, Hassan \& Baba, 2011) and older women tend to experience higher levels of chronic stress, lower levels of self-esteem and were less satisfied with life (Ong, Phillips, \& Chai, 2013).

Malaysia is aiming towards a developed nation by the year 2020, the social illness such as divorce rate, cyber-sex addiction and mental health problems are not aspired to be similar to that of the developed nations (Noor et al., 2014). Nevertheless, Malaysia is witnessing the steady increasing trend of the divorce rate. JAKIM (2010) reported in the last decade over 33,000 couples were divorced. It indicated that $0.22 \%$ of marriages among Malaysians aged from 18-50 ended in divorce, almost double to $0.13 \%$ as recorded in the year 2000 . Thus, based on the doubling rate, it is forecasted that by the year 2020 , the divorce rate will increase to at least $0.44 \%$.

As a result, more social illness of the divorce related cases will be witnessed. Younger generations may not have faith in marriage institutions and wellbeing single mothers and their children are at higher risks (Hassan, \& AlHorany, 2011). For younger women, $10 \%$ among college students addicted to cybersex (Cooper, 2013). 
Women are double (67\%) as compared to man (33\%) sexually addicted (Swisher, 1995). Studies indicate that sexual satisfaction is indeed important in marital wellbeing (Henderson-King \& Veroff, 1994).

Sexual satisfaction is a prime bio-psychosocial factor that helps stabilize the commitment in long term couple relationship Sprecher (2002) and buffer the life stress and marital conflicts (Litzinger \& Gordon, 2005).

Malaysia has witnessed an increasing interest in sexual related issues among researcher and mental health practitioner. Sexual dissatisfaction issues, especially among female, was a taboo to be discussed outside the bedroom has now taken places in conferences and clinics. Bio-psychosocial factors such as lack of sexual fitness (Brubaker, Shott, Tomezsko, \& Goldberg 2008), depression (Khoshbooii, Hassan, Hamzah, \& Baba, 2011) and cybersex addictions (Zakaria \& Baharudin, 2011, 2012) are among factors that lead to marital discord.

Barriers to diagnosis and treatment for sexual fitness (SF) may include the social stigma of the condition, the perception that treatment may require surgery (Culligan, 2012), and misconceptions that lack of SF may be normal for older women or after childbirth. It is believed that a "silent majority" of women lack of SF never seeks help and fails to implement self-help strategies that might have lessened the symptoms (Brubaker, et al., 2008). Primary care physicians routinely see younger women with milder symptoms, but often lack of time, interest, or training to adequately screen, evaluate and treat for SF. For these and other reasons, previous studies have shown that women who bring up the symptom with a health care professional may not receive appropriate information, and often are not provided effective treatment (Culligan et al., 2010).

Substantial evidences suggest the decline in libido is strongly related to the depth of depression in women (Kalmbach, Pillai, Kingsberg, \& Ciesla, 2014). Nevertheless, the assumption that depression among women lead to less sexual satisfactions and activities, as well as more sexual problems remain as an interpretive result (Bodenmann \& Ledermann, 2008). A depressed person experiences loss of interest in normally and previously enjoyed activities, hence, less likely to engage in sexual activities and achieve sexual satisfaction. Frohlich \& Meston (2002) investigated the relationship between depression and sexual problem on a large sample of undergraduate students aged 19-25 years old, found that the depressed students reported more difficulties in vaginal lubrication, experience more pain and have difficulties in reaching orgasm. Hence, depression as psychological factor may affect sexual satisfaction due to its symptoms regardless of age groups.

With the advent of smartphone, applications like WhatsApp allow mobile users to send real-time text messages, images, video, audio to individuals or groups of friends at no cost has both positive and negative effects to society like any other technology advancements. At present WhatsApp handles over 10 billion messages per day and is one of the most popular paid for apps across all mobile platforms (Church \& de Oliveira, 2013). One of the critical challenges of online technology is cybersex addictions among the youth. In the USA, it has been suggested that the increase in viewing of cybersex materials is due to easy access of those materials online. As of the year 2000, it has been estimated that nearly 20 million users visited sexual-related websites on monthly basis and this trend looks to continue as the search for sexual-related materials in the internet search engine has been ranked as the top searched items (Freeman-Longo, 2000). Although this trend sets to continue, it is unfortunate to note that research works on how to manage and prevent this addiction are not widely available. Cybersex addicts who compulsively used the internet pornography, adult chat rooms, or adult fantasy role-play sites most probably jeopardizing their mental health and real-life intimate partners (Zakaria \& Baharudin, 2011; 2012)

\section{Problem Statement}

Despite women play many significant roles in family and society, their well-being are at stakes. More than $80 \%$ of the middle-aged women experience some degenerative physical symptoms, $50 \%$ pelvic prolapse (Culligan, 2012), $65 \%$ marital distress and $22 \%$ divorces (Poomalar \& Arounassalame, 2013). Prolong marital conflicts lead to depression (Yahya \& Hassan, 2011; Symoens, Van de Velde, Colman, \& Bracke, 2013). Women are double as compare to man in depression (Khoosboii et al., 2011) and older women tend to experience higher levels of chronic stress, lower levels of self-esteem and were less satisfied with life (Ong et al., 2013). For younger women, $10 \%$ among college students addicted to cybersex (Cooper et al., 2013). Women are double (67\%) as compared to man (33\%) sexually addicted (Swisher, 1995).

Although Islam considers divorce as the necessary evil, the divorce rate may increase to at least $0.44 \%$ by the year 2020. In the year 2011, there is one divorce for every 15 minutes reported by JAKIM (2012). Divorce is permissible, yet it is very much discouraged. Unless it has become a threat to the married couple, marriage is a better choice than divorce and remains single. Johnston (2007) explained Islamic legal theory, known as maqasid as-shariah, one has the right to divorce when marriage has become a threat to; i) the deen (religion), nafs (soul), aql (cognition), nasl (descendent), and mal (wealth). Empty marriage, where married couples living together but do not consume conjugal relationships or sexually dissatisfied may pose danger not only to their psychological 
wellbeing (mental health) but also to their religion (Yahya \& Hassan, 2011). Concisely, Islam encourage neither divorce, nor empty marriage according to maqasid as-shariah (Khan, 2008).

Most probably due to embarrassment, Muslim women reserved sexual dissatisfaction within themselves. Even among the Euro-American, research indicates that very few clients try to seek face-to-face professional helps for increasing sexual satisfaction (Hucker \& McCabe, 2014). Unless, an attractive, comprehensive and trustworthy professional help is offered, Muslim women well-being may not be uplifted. They may receive an "ill-advice" and "help" from the internet in the form of sexual chat room and interactive porn games or movies and become addicted to cybersex. Worst of all, there are women who turned to be lesbian due to marital and sexual dissatisfaction ( Ghoroghi \& Hassan, 2015).

Almost all clients who experience sexual infidelity in their marital life experience Post Traumatic Stress Disorder (PTSD) similar to that of psychological symptoms due to tsunami and world war (Harun \& Yusof, 2011; Leone 2013). Indeed, divorced women are often confronted with stressful socio-economic status decline due to splitting household income and receiving sole custody of children without or very little alimony support (Symoens et al., 2013; Yahya \& Hassan, 2011). Accordingly, the lack of a soul mate, a move to another neighborhood, and reductions in social networks with family and friends after divorce decrease the amount of potential social support, just when high-quality support is needed most (Symoens et al., 2013). However, firm social networks, a stable job, a new partner, a high educational degree, and sufficient income can protect divorcees from getting too distressed by maximizing support and lowering financial worries. In particular, results show that women who have been divorced benefit more from higher education in terms of their sense of autonomy and their feelings of depression. Regarding feelings of competence, employment is also more strongly associated with better mental health among women than men after divorced.

To date, treatment on sexual relationships mostly limited to sexual dysfunction using medical and physical exercises (Litzinger \& Gordon, 2005). Few studies, if any, have conducted on Islamic psycho-spiritual treatment for sexual dissatisfaction. Results of our previous studies indicated that psychological treatment, Cognitive Behaviour Therapy, that embodied the Quranic Therapy to Muslim clients successfully decrease depression and increase sexual satisfaction (Khosbooii et al., 2011). In tandem to that, Group Cognitive Behavior Therapy that infused Quranic Therapy reduced parenting stress and increase marital adjustment (AlHorany, et al., 2011). We also found that another psychological treatment, Existential issues Training that integrates Quranic Therapy reduces existential anxiety of multiple roles responsibilities in women and improve marital communication and satisfaction (Kalantarkousheh et al., 2012). Effectiveness of our Marital Islamic Psycho-spiritual Intervention has also been documented (Ahmad \& Hassan, 2013) to increase spiritual and marital wellbeing. Consistently, previous findings provide support for the effectiveness of Islamic psycho-spiritual treatment (Hamjah, \& Akhir, 2014). Therefore, it is timely to propose a model of wellbeing based on Islamic transcendental theory (Al-Ghazali, 2010b; Hassan, Abdullah, Ishak, \& Langgulung, 2008).

\section{Objective of the Study}

Accordingly, we propose a holistic model of wellbeing for Malaysian Muslim women that integrates physical-sexual, socio-economical, and psycho-spiritual domains based on Islamic perspective of human nature. The model covers all dimension of human nature as described in the following sub-section. Moreover, the proposed model is also built upon the limitation of the existing wellbeing model.

\subsection{Human Nature}

In his inaugural lecture, Langgulung (2001) explained that human being is dual nature. The physical (jasd) is from the realm of creation ('alam al-khalq) and the spirit (ruh) is from the realm of order ('alam al-amr). The soul connect the physical and the spirit. The soul comes in three different forms as illustrated in Figure 1.

Langgulung, (2001), summarized the meaning of the four concepts that constitute human consciousness based on the works of the past Muslims scholars.

"Nafs is the place of the bad conduct, whereas ruh is the source of life and the place of good conduct. It is soft, pure and free from the influence of the nafs. It came from Allah and its existence is unobservable, it is also the place of love and mercy, whereas the Qalb is the place of Knowledge and the channels of perceptions. The Qalb cannot perceive unless it is free from the influence of the five senses. With performing zikir the laduni knowledge shed light to it. It is the place of knowledge. Aql they said is used for knowledge coming through the five senses using the thinking process. It is lower in rank than the Qalb. It is because both nafs and ruh tried to drag the qalb to its side that the qalb sometimes is influenced by the Ruh and other times by the Nafs." 


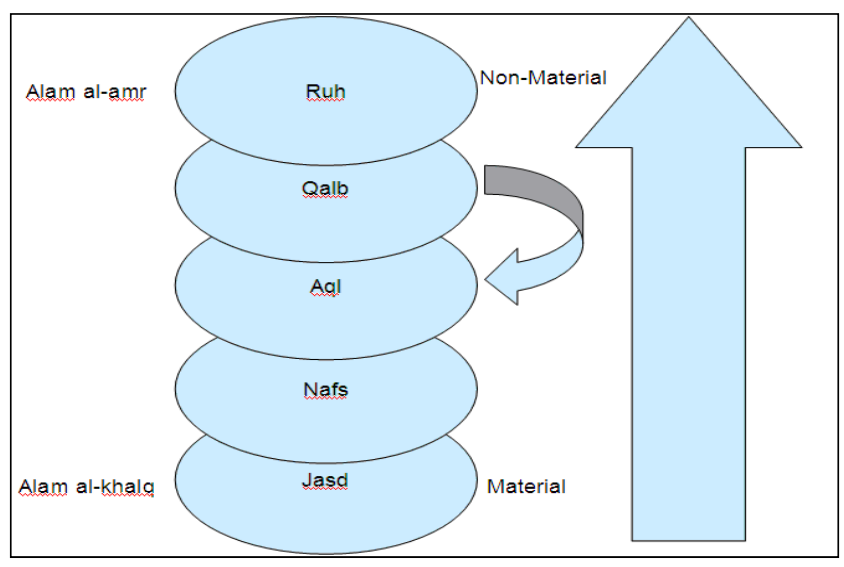

Figure 1. Human Consciousness (Source: Langgulung, 2001)

Then, Langgulung concluded that nafs, aql, qalb and ruh can be ranked in the ascending status as shown in Figure 1. Accordingly, based on Langgulung (2001) work, we derived a step further (Hassan, 2001; Hassan, Abdullah, Ishak, \& Langgulung, 2005). The dimension of human nature can be philosophically viewed as a six-layer sphere. The spirit is the center core of the sphere. This is the spiritual dimension of human being which always remains pure. Then, it is followed by the qalb, which is considered as emotional dimension. Then, the $a q l$, the intellectual dimension followed by the nafs, the physiological dimension. This is then followed by jasd, the physical and the last layer is "insan" the social dimension of human being. Thus, a cross section of this sphere is illustrated as in Figure 2.

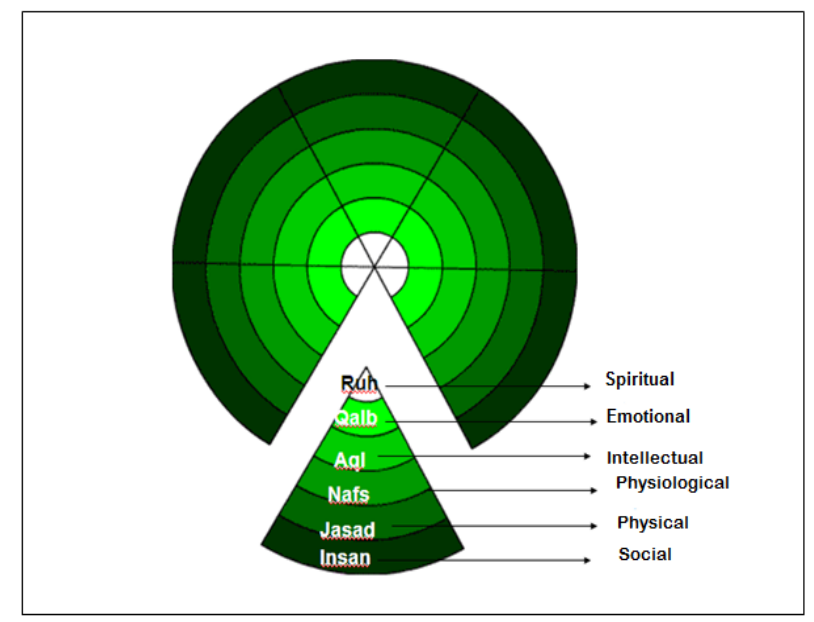

Figure 2. Dimensions of Human Nature (Source: Hassan, 2001, 2008)

Before discussing in detail the proposed six dimensions of human nature, it is noteworthy to understand the word human. In the Arabic Language, human means insan which is derived from the Arabic verb anisa to be sociable. From that word, then are the words of Insaniyyah, giving the meaning humanity and Insaniy means humanitarian (Raba, 2001).

\subsubsection{Social Dimension (The First Outer Layer)}

As noted earlier the word, "insan" means to be sociable thus, this dimension is pertinent in understanding human nature and behaviors. It is proposed as the first outer layer of human being. The first man, Adam (P.B.U.H) was created initially without any companionship. Then, Allah the Merciful created Hawa (Eve). From them, generations after generations are born until today. Thus, the very nature of human being is sociable. Accordingly, it is very important for the persons to consider whom their social contacts are.

The sociological dimension is very much influencing to human being. Most of the time it defines the needs of human if it is left unobserved by other dimensions. As an elaboration, the needs of certain kind of dressing, housing and so forth are culturally and socially determined. 
Muslim scholars are convinced that the secret of mental health lies in observing certain rights and obligations (Langgulung, 1989). To illustrate, the right of a husband is the duty of his wife and vice versa (Qudrawi, 1997). They further explained that a healthy person is the one who fulfills his or her personal as well as social duties to the best of his or her ability. The following verse is the code of conduct:

"Allah commands justice, and the doing good (i.e. kindness) to kith and kin, and He forbids shameful deeds and injustice and rebellion..." (Quran, 16: 90)

God does not burden any human being with more than he is well able to bear (2:2860)

Once the above teaching has been internalized, the person will remain free from worries and anxieties (AbdulRaheem, 1998).

\subsubsection{Physical Dimension (The Second Outer Layer)}

This dimension focuses on the jasd (body). It is proposed to be the second outer layer of the sphere. Contrary to Western view about the existent of the first human being as hypothesized by the Darwin, Haron Din (1991) summarized from The Holy Quran, that the first human (Adam) was created in bodily shape out of various combination of six types of earth and water. The six types of earth are stated in The Holy Quran as the following:
i. Al-Turab (al-Anbbiya:30)
ii. Al-Tin (al-Anbbiya:30)
iii. Al-Tin Al-Lazib (As-Sffat:11)
iv. Hamaein Masnun (Al-Hijr:28)
v. Salsaalin kal-fakhar (Ar-Rahman:14)
vi. $\quad$ Al-Ard (An-Najm:32)

Accordingly, the process of the Adam genesis is described in the following verses.

"...We created you out of dust, then out of sperm, then out of a leech-like clot, then out of a morsel flesh, partly formed and partly unformed, in order that we may manifest (Our power) to you... "

(Quran, 22: 5)

\subsubsection{Physiological Dimension (The Third Outer Layer)}

Then the reactivity of the jasd and nafs, in specific the sexual intercourse which then brings lives to physical genesis is one of the most significant in physiological dimension.

The third dimension of human nature is the nafs (physiological dimension) which is interrelated between physical and emotional (Langgulung, 1989).

"Was he not a drop of sperm emitted in lowly form?"(Quran, 75:30)

The physiological needs are in fact very much important to be fulfilled. This is clearly stated in various verses in the Holy Quran. Among them is

"O children of Adam! Wear your beautiful apparel at every time and place of prayer: eat and drink: but waste not by excess, for God loved not the wasters."

(Quran, 7:31)

Prophet Muhamamd (P.B.U.H) is the "living Quran" also emphasizes the importance of this dimension. Thus, he opposed the plan of sahabah (companion) to fast every day and not to marry.

\subsubsection{Intellectual Dimension}

The faculty of intellect of human nature is one of the biggest ni'mah (blessing) bestowed by Allah to humankind. It is proposed as this is the fourth outer and the third inner layer of human nature. This intellectual dimension is what differentiates us from an animal as a basic principle in order to understand human beings. As unique as the human fingerprint, so does human thought. Thus, with this special gift given to us we are obligated to actualize the potential. Seeking and disseminating knowledge is thus obligatory upon each individual.

Aql in the Arabic literature means determination, logic and judgment. The Holy Quran mentions at least 49 times about thinking, memorizing and imagining (Raba, 2001). It motivates a human being to use this faculty inductively and deductively.

The Quran (Yunus: 24) reminds us. 
"Worldly life may be compared to water We send down from the sky. It mingles with the plants of the earth on which mankind and life stock feed until, when the earth takes on its trimmings and looks attractive, and its people think that they will be able to use them as they like. Our command comes along to it by night or daytime, and We mow it down ahead of time just as though it had not been so lush the day before. Thus We spell out signs for folk who will think things over".

In another verse,

"In the creation of the heavens and the earth, and in the alteration of night and day, there are signs for men of sense." (Al-Quran: 3: 190)

\subsubsection{Emotional Dimension}

Qalb (heart) is the place where real faith, true feelings or emotions are stored and shown in human behavior. The Holy Quran uses the word qalb and fuad because the word fuad means the heart of the heart or the cover of the heart. For example, remembering Allah (swt) is the work of the heart, performing worships and all good actions are derived from the sincerity, which is derived from the heart (Raba, 2001).

The following verses describe the important of taking care this dimension

"We will turn away their hearts and eyes (from truth) since they refused to believe it at the first. We will learn them to blunder about it in their wrong doing."

(Al-Quran, 17:37)

According to Al- Ghazali (2010b), the heart is like the mirror receiving knowledge through light of faith. The heart of the child is immature to receive and understand the reality. The heart of the sinner that has become dark cannot show knowledge on it.

As proposed earlier, this is the layer that comes right before the spiritual dimension. Thus, to safeguard this dimension is to take care the inner core of human dimension. To take care of the heart is actually to take care of one self.

\subsubsection{Spiritual Dimension}

Muslim psychologists considered this dimension the distinguishing factor between Islamic and the Western psychology. This dimension has purposely being ruled out by materialistic and positivistic scholars as explained earlier. The spirit is considered as the core of the human nature sphere. This dimension is always pure and seeks the purity. Thus, one can only be in the eternal bliss and felicity if this dimension is taken care of. Human has the potential of being the true believer from the very beginning. This can be evident from the covenant of the children of Adam have committed in the following verse.

"When your Lord took their offspring from the children of Adam's loins, and made them bear witness about the selves. Am I not your Lord? They Said: Of course, we testify to it. Lest you all might say on resurrection day: we were unaware of it." (Al-Quran, 7:172)

Since that time, every human being has been testifying that Allah is Their Lord, the Only One. In fact, the whole Quran as well as the previous books of Allah has been dedicated for this teaching. This fact is clearly stated in another verse (Ar-Rum: 30) as below:

"Therefore set your face in devotion to the true faith, the upright nature with which Allah has endowed man. Allah's creation cannot be changed. This is the true religion, although most men do not know"

However, if the other dimension of self is not taken care of, this dimension is affected. As mentioned before if the heart is full of sin then the light of truth can never penetrate. Similarly, if the social dimension is corrupted then, this dimension is affected as well. The hadith mentions the importance of the environmental factor. Prophet Muhammad (P.B.U.H) described the parents being the determiner of the children's faith whether to be Muslim, Jew, Christian or the idol worshiper.

When human beings go against their very own nature they become ill. This is the humble finding that is proposed to be integrated in counseling the clients. Being faithful to Allah is man's nature and this cannot be changed. Therefore, when foreign element discolors his true nature he becomes chaotic in all his dimensions and eventually faces stress, guilt, emotional disturbance and poor health.

\subsection{Wellbeing Model}

Currently, most of the available wellbeing models position spiritual wellbeing of the same level with other dimension as shown in Figure 3. 


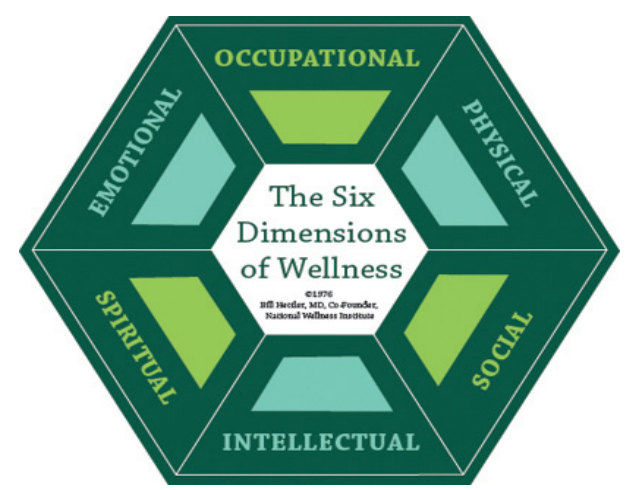

Figure 3. The six dimensions of wellness model (Bill Hettler, 1976)

Hettler (1976) explain the Six Dimensions of Wellness Model as a holistic model. It shows how a person contributes to his or her environment, community, and how to build better living spaces and social networks. In occupational dimension, is explained the enrichment of life through work, and its interconnectedness to living and playing in social dimension. The development of belief systems, values, and creating a world-view is in the spiritual dimension. While the physical dimension stress on the benefits of regular physical activity, healthy eating habits, strength and vitality, as well as personal responsibility, self-care and when to seek medical attention. Emotional dimension is to enhance self-esteem, self-control, and determination as a sense of direction. Intellectual is being creative and stimulating mental activities, and sharing them with others.

\section{Holistic Model for Malaysian Muslim Women Wellbeing}

According to Islamic transcendental theory Al-Ghazali (2010 b), spiritual dimension is the central and permeates to other dimension as we discussed earlier (Hassan, 2001; 2011). It is an inner out approach. Spiritual dimension (ruh) is always pure and it is the source of light (nur) and life. Where the emotional dimension (qalb) is like the glass that contain the light. If the glass is clean, the light penetrates clearly to other dimension. We suggest that the intellectual dimension $(a q l)$ is like mirror that reflect the light from ruh and captures or shows the images of other dimensions.

Therefore, we proposed another holistic model of wellbeing for Muslim women in Malaysia. Figure 3 illustrates that spiritual domain is the central of Muslim women's wellbeing model. From the spiritual wellbeing, transcends other domains of wellbeing. According to anti-clock wise, the model shows that psychological wellbeing of women is affected by and overlap with their sexual wellbeing. Then, sexual wellbeing is affected by and overlap with their physical wellbeing. Next, physical wellbeing is affected by and overlap with their social wellbeing. Accordingly, social wellbeing is affected by and overlap with their economic wellbeing. Finally, economic wellbeing is affected by and overlap with their psychological wellbeing. Hence, a complete cycle of women's wellbeing shows interrelation from one domain to another.

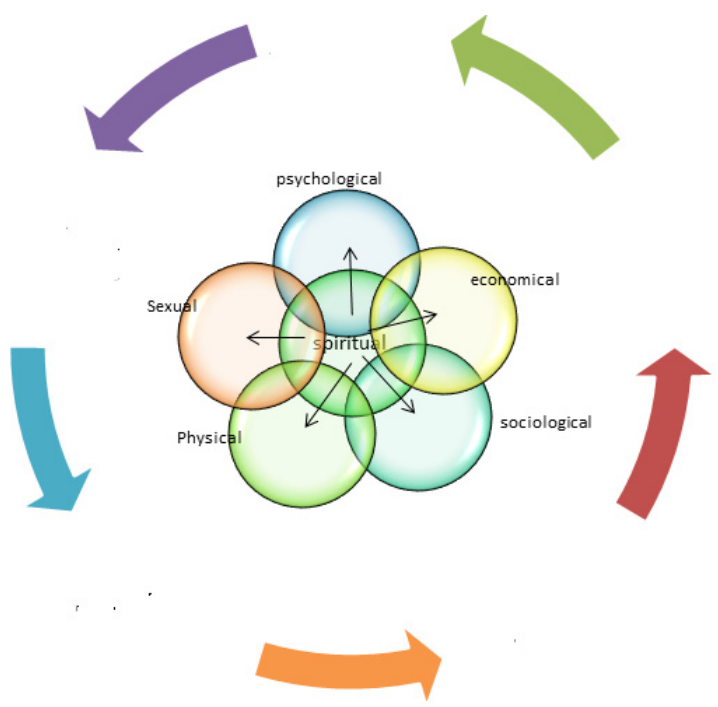

Figure 3. The proposed Islamic transcendental wellbeing model (ITWM) for women 


\section{Counseling Implication}

Lent (2004) suggests that clients often seeks counseling for a wide array of problems, that may probably be categorized into two types. Type A "The unhappy client" who seeks help for symptom relief and restoration of life satisfaction and Type B "The self-actualizing client" who seeks for growth, learning, change, or understanding.

Type A clients are typically experiencing heightened negative affect and diminished positive affect and Their sense of wellbeing most likely diminished and destabilized their sense of coping efficacy.

Type B clients are often desire to learn or develop. They want to be "better than well," as it were. Typically, they may express existential concerns such as a wish to find purpose or meaning in their lives.

Nevertheless, it is also common to see Type A clients eventually become Type B clients. They seek to extend the focus of counseling and prolong the counseling process. Understanding the type of clients may help reduce tensions and misunderstandings between counselor and client.

In the beginning phase of the counseling process, for setting the counseling objectives and approach, Type A client may only wish to achieve symptom relief and then be off they go but the, but the counselor who is convinced that longer term, growth-oriented counseling may privately disparage such client motivations, referring to symptom-focused counseling as merely "band-aiding" the client's problems. On the other hand, it also common to see that counselor especially among the novice, moving too quickly toward prescribing actions to help the client feel better. Yet, we do not imply an irreconcilable dichotomy between the two. Rather it is interrelated of negative affect reduction and positive affect increment.

In the working phase, growth is eventually taken place when Type A clients need to change some aspect of their life in order to avoid recurring pain and maintain lasting happiness. They then become Type B client. With the Islamic holistic approach, where spiritual is the core, we consider focusing on spiritual dimension are beneficial for both Type A and Type B client. Nevertheless, the novice counselor or at least novice in Islamic transcendental and pyscho-spiritual may likely tends to prescribe treatment for quick fix solution (Hamjah \& Akhir, 2014). Until and unless, the client Type A is moving toward Type B, who is already enlighten and moving toward holistic wellbeing, then counselor has to be more of modeling on Islamic manner rather than a preacher. Even that, applying Islamic Transcendental Wellbeing Model in the counseling process is not only about talking but also doing and feeling (Al-Ghazali, 2010 a). In other words, as discussed by Langgulung(1986) Hamjah (2008) and Hassan (2011) first is to purify (takhalli) from the vices, then to beautify (tahalli) with virtues. The processes then continue untill the clients experience the sweetness of faith (tajalli). Thus, it marks the end of the counseling process.

In a nutshell, Islamic Transcendental Wellbeing Model (ITWM) for women highlights the important spiritual domain as inner resources for them to be healthy, feel happy and achieve prosperity. This model propagates of holistic approach that was propagated by Langgulung (1989) and Hassan (2011), hence it begins with spiritual dimension in counseling process. Yet, the counselors are not to prescribe religious quick fix solution by providing cheap advice especially for type B clients. They are to model themselves of experiencing the sweetness of faith from the spiritual dimension, then it permeates into all domain of wellbeing.

\section{Acknowledgements}

The author would like to acknowledge The Ministry of Education for providing the grant ERGS /1/2013/SS02/UPM/02/1

\section{References}

Ahmad, H., Baba, M., \& Hassan, S. A. (2009). Work-family conflict and its antecedents among single mother employees. The International Journal of Interdisciplinary Social Sciences, 4.

Al-Ghazali, A. H. M. (2010a). Deliverance from Error and the Beginning of Guidance (W. M. Watt Trans.). Kuala Lumpur: Islamic Book Trust. (Original work published 1924).

Al-Ghazali, A. H. M. (2010b). The Message From On High (M. Smith Trans.). Kuala Lumpur: Islamic Book Trust. (Original work published 1924).

Alhorany, A., Hassan, S. A., Baba, M., \& Juhari, R. (2011). Efficacy of group cognitive behavioral therapy on depression among Muslim parents of autistic children in Jordan. Australian Journal of Basic and Applied Sciences, 5(12), 827-832.

AlHorany, A. K., Younis, N. A., Batainah, M. Z., \& Hassan S. A. (2013). Do mothers of children with autism are 
at higher risk of depression? A review of literature. Life Science Journal, 10(1), 3303-3308.

Ali, A. Y. (2000). The Holy Qur'an: Origina Rabic Text with English Translation and selected commentary. Kuala Lumpur: Saba Islamic Media.

Askari, M., Noah, S. B. M., Hassan, S. A. B., \& Baba, M. B. (2012). Comparison the effects of communication and conflict resolution skills training on marital satisfaction. International Journal of Psychological Studies, 4(1), 182. http://dx.doi.org/10.5539/ijps.v5n1p182

Azahari, R. (2010). The Development of Family Mediation in Malaysian Muslim Society. European Journal of Social Sciences, 18(2), 220-230.

Bill Hettler, M. D. (1976). The Six Dimensions of Wellness Model. Retrieved June 10, 2014, from http://www.nationalwellness.org

Bodenmann, G., \& Ledermann, T. (2008). International Journal of Sexual Health, 19, 63-73. http://dx.doi.org/10.1300/J514v19n04-07(CD)(SX)

Brubaker, L., Shott, S., Tomezsko, J., \& Goldberg, R. P. (2008). Pelvic floor fitness using lay instructors. Obstetrics \& Gynecology, 111(6), 1298-1304.

Chlen, S., \& Mustaffa, M. S. (2008). Divorce in Malaysia. In Proceedings of the Seminar Kaunseling Keluarga, Aug (Vol. 30, pp. 23-28). http://dx.doi.org/10.3923/jas.2009.3758.3763

Church, K., \& de Oliveira, R. (2013, August). What's up with WhatsApp?: comparing mobile instant messaging behaviors with traditional SMS. In Proceedings of the 15th international conference on Human-computer interaction with mobile devices and services (pp. 352-361). ACM.

Cooper, A. (Ed.). (2013). Cybersex: The Dark Side of the Force: A Special Issue of the Journal Sexual Addiction and Compulsion. Routledge.

Culligan, P. J. (2012). Nonsurgical management of pelvic organ prolapse. Obstetrics \& Gynecology, 119(4), 852-860. http://dx.doi.org/10.1097/AOG.0b013e31824c0806

Culligan, P. J., Scherer, J., Dyer, K., Priestley, J. L., Guingon-White, G., Delvecchio, D., \& Vangeli, M. (2010). A randomized clinical trial comparing pelvic floor muscle training to a Pilates exercise program for improving pelvic muscle strength. International urogynecology Journal, 21(4), 401-408. http://dx.doi.org/10.1007/ s00192-009-1046-z

Da Silva Borin, L. C. M., Nunes, F. R., \& de Oliveira Guirro, E. C. (2013). Assessment of Pelvic Floor Muscle Pressure in Female Athletes. $P M \& R$, 5(3), 189-193. http://dx.doi.org/10.1016/j.pmrj.2012.09.001

Dasar Wanita Negara. (1986). Retrieved June 1, 2014, from http://pmr.penerangan.gov.my/index.php/maklumatkenegaraan/249-dasar-wanita-negara.html

Din, H. (1991). Manusia dan Islam. Kuala Lumpur: Dewan Bahasa dan Pustaka.

Freeman-Longo, R. E. (2000). Children, teens, and sex on the Internet. Sexual Addiction \& Compulsivity: The Journal of Treatment and Prevention, 7(1-2), 75-90.

Frohlich, P., \& Meston, C. (2002). Self-reported depressive symptoms among college women. The Journal of Sex Research, 39, 321-325.

Ghoroghi, S., Hassan, S. A., \& Baba, M. (2012). Function of Family-of-Origin experiences and marital adjustment among married Iranian students. International Journal of Psychological Studies, 4(3), 94-103. http://dx.doi.org/10.5539/ijps.v4n3p94

Ghoroghi, S., \& Hassan, S. A. (2015). Students' cybersex casual activities In Malaysia. In press.

Hamjah, S. H. (2008). Pendekatan Da'wah Al-Irsyad Al-Nafsiyy Menurut Al-Ghazali: Satu Kajian Di Pusat Kaunseling Majlis Agama Islam Negeri Sembilan [Al-Irsyad Al-Nafsiyy Missionary Approach According to Al-Ghazali: A case study at Counseling Centre of Department Religious Affair Negeri Sembilan] (Doctoral dissertation, Universiti Sains Malaysia).

Hamjah, S. H., \& Akhir, N. S. M. (2014). Islamic Approach in Counseling. Journal of religion and health, 53(1), 279-289. http://dx.doi.org/10.1007/s10943-013-9703-4

Harun, L. M., \& Yusof, S. N. M. (2011). Kecurangan didalam rumahtangga [Infidelity in marital relationship]. Dalam Siti Aishah Hassan. Menangani Masalah Komuniti: Pendekatan Psikospiritual, Kaedah E-Kaunseling, dan Pelaksanaan Modul (pp. 8-25). Serdang: Penerbit UPM. ISBN: 978-967-344-256-0 
Hassan, S. A. (2011). Teori Kaunseling Psikospiritual Islam. Dalam Siti Aishah Hassan. Menangani Masalah Komuniti: Pendekatan Psikospiritual, Kaedah E-Kaunseling, dan Pelaksanaan Modul (pp. 8-25). Serdang: Penerbit UPM. ISBN: 978-967-344-256-0

Hassan, S. A., \& Al Horany, A. (2011). Marital adjustment among postgraduate students at universities in Malaysia. Elixir Psychology, 37, 3773-3776.

Hassan, S. A., Abdullah A. S., Ishak, N., \& Langgulung, H. (2008). Measuring the unmeasurable: Maternal piety scales. Pertanika Journal of Social Sciences, 16(1), 95-105.

Hassan, S. A., Abdullah, A. S., Langgulung, H., \& Ishak, N. (2005). Fostering Mother-Child Relationship via Creator-Creature Relationship: A Structural Equation Modelling Analysis. Journal of Malaysian Psychology, 19, 69-82.

Hassan, S. A. (2001). Stress counseling for employed mothers: An Islamic approach of dimensional self. Paper presented at Seminar Kaunseling Kebangsaan Ke III, Universiti Utara Malaysia. Oct. 27.

Henderson-King, D. H., \& Veroff, J. (1994). Sexual satisfaction and marital well-being in the first years of marriage. Journal of Social and Personal Relation ships, 11(4), 509-534.

Hucker, A., \& McCabe, M. P. (2014). Incorporating mindfulness and chat groups into an online cognitive behavioral therapy for mixed female sexual problems. The Journal of Sex Research, (ahead-of-print), 1-13.

Isherwood, P. J., \& Rane, A. (2000). Comparative assessment of pelvic floor strength using a perineometer and digital examination. BJOG: An International Journal of Obstetrics \& Gynaecology, 107(8), 1007-1011. http://dx.doi.org/10.1111/j.1471-0528.2000.tb10404.x

JAKIM. (2010). Statistik penceraian 2000-2009. Jabatan Kemajuan Islam Malaysia

JAKIM. (2012). Statistik penceraian 2010-2011. Jabataan Kemajuan Islam Malaysia

Jalovaara, M. (2001). Socio-economic status and divorce in first marriages in Finland 1991-93. Population Studies, 55(2), 119-133. http://dx.doi.org/10.1080/00324720127685

Johnston, D. L. (2007). Maqasid Al-Shariah: Epistemology and hermeneutics of Muslim theologies of human rightss. Die welt des Islams, 47, 2.

Kalantarkousheh, S. M., Hassan, S. A., Kadir, R. A., \& Talib, M. A. (2012). Effects of existential issues training on marital satisfaction among Iranian women. The New Educational Review, 28(2), 29-38.

Kalmbach, D. A., Pillai, V., Kingsberg, S. A., \& Ciesla, J. A. (2014). The transaction between depression and anxiety symptoms and sexual functioning: A prospective study of premenopausal, healthy women. Archives of sexual behavior, 1-15.

Khan, F. (2008). Traditionalist Approaches to Shariah Reform: Mawlana AshrafAli Thanawi's Fatwa on Women's Right to Divorce. ProQuest.

Khoshbooii R., Hassan, S. A., Hamzah, M. S. G., \& Baba, M. (2011). Effectiveness of group cognitive behavioral therapy on depression among Iranian women around menopause. Australian Journal of Basic and Applied Sciences, 5(11), 991-995.

Kwan, L. L. Y., Mellor, D., Rizzuto, L., Kolar, C., \& Bt. Mamat, N. H. (2013). The Relationship Between Perceived Interparental Conflict and Malaysian Young Adults' Attitudes Toward Divorce. Journal of Divorce \& Remarriage, 54(7), 596-607. http://dx.doi.org/10.1080/10502556.2013.828989

Langgulung, H. (1986). Manusia dan pendidikan. Suatu Analisa Psikologi dan Pendidikan, Jakarta: Alhusna.

Langgulung, H. (1989). Research in psychology: Toward an ummatic paradigm. IIIT: Toward Islamization of disciplines. Herndon: IIIT, 115-130.

Langgulung, H. (2001). A Psycho-pedagogical Approach to Islamization of Knowledge: Inaugural Lecture Delivered on 16th May 2001, Ground Floor, Research Centre, IIUM. Research Centre, International Islamic University Malaysia.

Lent, R. W. (2004). Toward a Unifying Theoretical and Practical Perspective on Well-Being and Psychosocial Adjustment. Journal of Counseling Psychology, 51(4), 482.

Leone, C. (2013). Helping Couples Heal From Infidelity: A Self Psychological, Intersubjective Approach. International Journal of Psychoanalytic Self Psychology, 8(3), 282-308.

Litzinger, S., \& Gordon, K. C. (2005). Exploring relationships among communication, sexual satisfaction, and 
marital satisfaction. Journal of sex \& marital therapy, 31(5), 409-424.

Momtaz, Y. A., Hamid, T. A., Masud, J., Haron, S. A., \& Ibrahim, R. (2013). Dyadic effects of attitude toward aging on psychological well-being of older Malaysian couples: an actor-partner interdependence model. Clinical interventions in aging, 8, 1413.

Noor, N. M., Gandhi, A. D., Ishak, I., \& Wok, S. (2014). Development of Indicators for Family Well-Being in Malaysia. Social Indicators Research, 115(1), 279-318.

Nor, A. M., Karim, D. N. F. M., Jaladin, R. A. M., \& Ahmad, N. (2013). From nasty to healthy divorce: A marriage and family therapy model for working effectively with divorcing Malay-Muslim Couples. Malaysian Online Journal of Counseling, 1(1).

Ong, F. S., Phillips, D. R., \& Chai, S. T. (2013). Life events and stress: do older men and women in Malaysia cope differently as consumers? Journal of Cross-cultural Gerontology, 28(2), 195-210. http://dx.doi.org/10.1007/s10823-013-9190-9

Poomalar, G. K., \& Arounassalame, B. (2013). The quality of life during and after menopause among rural women. Journal of clinical and diagnostic research: JCDR, 7(1), 135.

Raba, A. M. (2001). Major personalities in the Quran. Kuala Lumpur: AS Noordeen.

Sadiqi, F. (2008). The Central role of the family law in the Moroccan Feminist Movement. British Journal of Middle Eastern Studies, 35(3), 325-337. http://dx.doi.org/10.1080/13530190802525098

Sprecher, S. (2002). Sexual satisfaction in premarital relationships: Associations with satisfaction, love, commitment, and stability. Journal of Sex Research, 39(3), 190-196. http://dx.doi.org/10.1080/0022449020 9552141

Swisher, S. H. (1995). Therapeutic interventions recommended for treatment of sexual addiction/compulsivity. Sexual Addiction \& Compulsivity: The Journal of Treatment and Prevention, 2(1), 31-39.

Symoens, S., Van de Velde, S., Colman, E., \& Bracke, P. (2013). Divorce and the Multidimensionality of Men and Women's Mental Health: The Role of Social-Relational and Socio-Economic Conditions. Applied Research in Quality of Life, 1-18.

Wan-Ibrahim, W. A., Majid, M. A., \& Zainab, I. (2014). Subjective Well-Being of Older Persons at Elderly Day-Care Center. Middle-East Journal of Scientific Research, 20(11), 1461-1464. http://dx.doi.org/10.5829/ idosi.mejsr.2014.20.11.21081

Weissman, M. M., \& Klerman, G. L. (1977). Sex differences and the epidemiology of depression. Archives of general psychiatry, 34(1), 98.

Yahya, Z., \& Hassan, S. A. (2011). Model Kaunseling Penceraian Maqasid Syariah [ Maqasid Shariah Divorce Counseling Model]. Dalam Siti Aishah Hassan. Menangani Masalah Komuniti: Pendekatan Psikospiritual, Kaedah E-Kaunseling, dan Pelaksanaan Modul (pp. 26-58). Serdang: Penerbit UPM.

Zainab, I., Wan-Ibrahim, W. A., \& Asyraf, H. A. R. (2014). Marital Breakdown in Muslim Community in Malaysia. Middle-East Journal of Scientific Research, 20(11), 1440-1444. http://dx.doi.org/10.5829/idosi. mejsr.2014.20.11.21072

Zakaria, M. Z., \& Baharuddin, D. F. (2011a). Cybersex Addiction Treatment a Malaysian Perspective on The Needs for Counselors Training. PERKAMA International Conference Bandung, Indonesia, 7-9 December.

Zakaria, M. Z., \& Baharudin, D. F. (2011b). Ketagihan Seks Siber: Pengalaman Kaunselor di Malaysia. PERKAMA International Convention. Kuala Lumpur: 22-23June.

\section{Copyrights}

Copyright for this article is retained by the author(s), with first publication rights granted to the journal.

This is an open-access article distributed under the terms and conditions of the Creative Commons Attribution license (http://creativecommons.org/licenses/by/3.0/). 